\title{
CD27 distinguishes two phases in bone marrow infiltration of splenic marginal zone lymphoma
}

\author{
V Franco, A M Florena, S Ascani, ${ }^{1}$ M Paulli, ${ }^{2}$ M Salvato \& S A Pileri ${ }^{1}$ \\ Istituto di Anatomia e Istologia Patologica, University of Palermo, Palermo, ${ }^{1}$ Anatomia Patologica, \\ Istituto di Ematologia e Oncologia Medica, University of Bologna, Bologna, and ${ }^{2}$ Department of Pathology, \\ IRCCS Policlinico S. Matteo/University of Pavia, Pavia, Italy
}

Date of submission 7 May 2003

Accepted for publication 18 May 2003

Franco V, Florena A M, Ascani S, Paulli M, Salvato M \& Pileri S A

(2004) Histopathology 44, 381-386

\section{CD27 distinguishes two phases in bone marrow infiltration of splenic marginal zone lymphoma}

Aims: To investigate CD27 expression in splenic marginal zone lymphoma (SMZL), an indolent low-grade B-cell lymphoma with constant involvement of the bone marrow, especially with an intrasinusoidal pattern. It is not clear if the neoplastic clone is composed of virgin or somatically mutated B cells. CD27 is reported to be a hallmark of memory B cells.

Methods and results: We evaluated 64 bone marrow biopsy specimens (BMBs) from 36 patients with SMZL for the expression of $\mathrm{CD} 27$. For comparison, splenectomy specimens of patients with traumatic splenic rupture or with SMZL were used. All BMBs showed lymphomatous infiltration. When located in the marrow sinusoids, neoplastic cells were CD27- in all cases and therefore corresponded to naive $\mathrm{B}$ cells. In nodular/interstitial infiltration, the cells were CD27+ and therefore corresponded to memory B cells. No difference in immunohistochemical expression of $\mathrm{B}$ and $\mathrm{T}$ antibodies was found between intrasinusoidal and interstitial/nodular infiltration. CD27 was constantly expressed in the splenic marginal zone of normal spleen, surgically removed for trauma, and in seven out of 10 spleens with SMZL.

Conclusion: We propose the existence of two different phases of neoplastic progression with, first, expansion of a virgin B clone in the bone marrow and, following exposure to antigen, a re-colonization of the bone marrow.

Keywords: bone marrow, CD27, intrasinusoidal infiltration, naive and memory B cells, splenic marginal zone lymphoma

Abbreviations: BMB, bone marrow biopsy specimen; SMZL, splenic marginal zone lymphoma

\section{Introduction}

CD27 is an antigen involved in T-B-cell interaction and is expressed on both T and B cells. ${ }^{1}$ The function of $\mathrm{CD} 27$ is not completely known but it seems to be involved in promoting lymphocyte expansion and effector cell formation through interaction with its ligand CD70. ${ }^{2}$ $\mathrm{CD} 27$ has been recently identified as a specific marker for memory B cells. ${ }^{3,4}$ Memory B cells carry somatically

Address for correspondence: Professor Vito Franco, Istituto di Anatomia e Istologia Patologica, Policlinico, Via del Vespro 129. 90127 Palermo, Italy. e-mail: vfranco@unipa.it mutated variable region genes and constantly express CD27, while naive B cells do not. ${ }^{5}$ The unmutated naive CD27- population comprises $60 \%$ of peripheral blood B cells. ${ }^{6}$ Three-quarters of these cells are CD5- and constitute the naive precursor of germinal centre cells. The memory CD27+ B-cell population is represented by somatically mutated postgerminal centre cells and comprises $40 \%$ of peripheral blood B cells in humans, in contrast to $5 \%$ in mice. ${ }^{6}$ The majority of $\mathrm{B}$ cells in the rat splenic marginal zones are naive B cells, as judged by the lack of somatic hypermutation, that may be ligand selected. $^{7}$

Memory B cells are present in the human adult splenic marginal zone. The vast majority of marginal 
zone B cells in the adult spleen express CD27. ${ }^{1}$ In contrast, the splenic marginal zone of infants and young children is populated by naive B cells, which are replaced by memory B cells in a time frame of 2-5 years. $^{8}$

Splenic marginal zone lymphoma (SMZL) was originally purported to originate from postgerminal centre memory B cells that usually have mutated immunoglobulin heavy-chain variable $\left(\mathrm{V}_{\mathrm{H}}\right)$ genes. ${ }^{9}$ However, the vast majority of SMZL expresses both IgD and IgM, which is more typical of naive cells with unmutated $\mathrm{V}_{\mathrm{H}}$ genes.

About half of the cases studied by Algara et al. were unmutated. ${ }^{10}$ The same percentage was found by Bahler et al., who suggested the existence of two different types of SMZL: one that originates from naive $\mathrm{B}$ cells, in addition to one that originates from memory marginal zone B cells. They also proposed that antigen selection might be occurring during lymphomagenesis. ${ }^{11}$ Sekikawa et al. found no somatic mutation in the $\operatorname{IgV}_{\mathrm{H}}$ sequence in cells from peripheral blood and spleen in a case of SMZL with macroglobulinaemia. ${ }^{12}$

In order to elucidate the cell of origin and the histogenetic mechanism in SMZL, we investigated CD27 expression in bone marrow biopsy specimens (BMBs) in a series of 36 patients, along with a complete immunohistochemical study using a wide panel of antibodies.

\section{Materials and methods}

Sixty-four BMBs were obtained from 36 patients. All patients selected for this study were diagnosed with SMZL. The diagnosis was made on splenectomy specimens or BMB. The histological study was performed on Schaffer-fixed paraffin-embedded BMBs using haematoxylin-eosin, periodic acid-Schiff, Giemsa and Gomori stains. Immunohistochemistry was performed on BMBs by means of the avidin-biotin-peroxidase complex, using the monoclonal antibody $\mathrm{CD} 27$ (Novocastra Laboratories, Newcastle upon Tyne, UK) at a dilution of $1: 40$, along with the following antibodies: CD45 (leucocyte common antigen), CD20, CD79a, CD43, CD3, CD5, CD10, CD23, Bcl-2, Bcl-6. As controls, five normal spleens following splenectomy for trauma and 10 spleens with SMZL were used.

\section{Results}

The patients included 22 men and 14 women. The median age was 65 years (range 23-82). Twenty patients had two or more BMBs. All BMBs had lymphomatous infiltration ranging from 10 to $90 \%$ of overall cellularity. An intrasinusoidal pattern of infiltration was evident in all cases, alone or in association with nodular and/or interstitial patterns. In patients with multiple BMBs, a change or increase in the nodular component was noted, but never the opposite, i.e. a change from nodular to intrasinusoidal. CD27 was found to be positive in all cases which displayed nodular infiltration (Figure 1a), while the cells in an intrasinusoidal location were constantly negative (Figure $1 b$ ). In mixed infiltrations, the cells maintained this pattern of reactivity, i.e. positivity in the nodules and negativity in the sinuses. With the other antibodies there was no difference between the intrasinusoidal and interstitial/nodular pattern and in all cases the infiltration was positive for CD45, CD20, CD79a, Bcl-2, and negative for CD43, CD3, CD5, CD10, CD23, and Bcl-6. In the splenic marginal zone of the spleen removed for trauma, the vast majority of the cell population was CD27+ (Figure 1c). Occasional positive cells were seen in mantle zones and germinal centres. In the spleens with SMZL, CD27 was found to be positive in seven out of 10 cases (Figure 1d). However, even in negative cases the marginal zone of residual follicles was positive.

\section{Discussion}

Naive B cells arise in the bone marrow, where they undergo so-called 'antigen-independent' development. A further phase takes place with the activation by nonself antigens and migration from bone marrow to spleen. ${ }^{13}$ It has been estimated that only about $15-20$ million immature $\mathrm{B}$ cells made each day in the mouse bone marrow emerge as mature cells in the periphery. ${ }^{14}$ Naive B cells leave the bone marrow and enter the peripheral blood as IgM+ IgD+ cells. In the germinal centre, the antigen-dependent stage of B-cell development takes place. The sequence and structure of the antigen-binding site can be altered through a process of somatic hypermutation that is targeted at the $\mathrm{V}$ domain, leading to a change in the binding affinity and specificity of the antibody. ${ }^{15-17}$ Several studies have interpreted findings of non-random $\operatorname{IgV}_{\mathrm{H}}$ gene utilization and $\mathrm{V}$ region mutation to suggest that a lymphoma derives from a normal cell that is antigen experienced and has passed through the germinal centre. ${ }^{18,19}$ In addition, a second type of recombination event, termed class switch recombination, occurs in the germinal centres where the B cell changes its antibody effector function, while maintaining the antigen specificity of the original antibody. ${ }^{20}$

Human CD27 is a B-cell costimulatory molecule, which is able to inhibit the p53-independent mitochondrial pathway for apoptosis of $\mathrm{B}$ cells and is a 

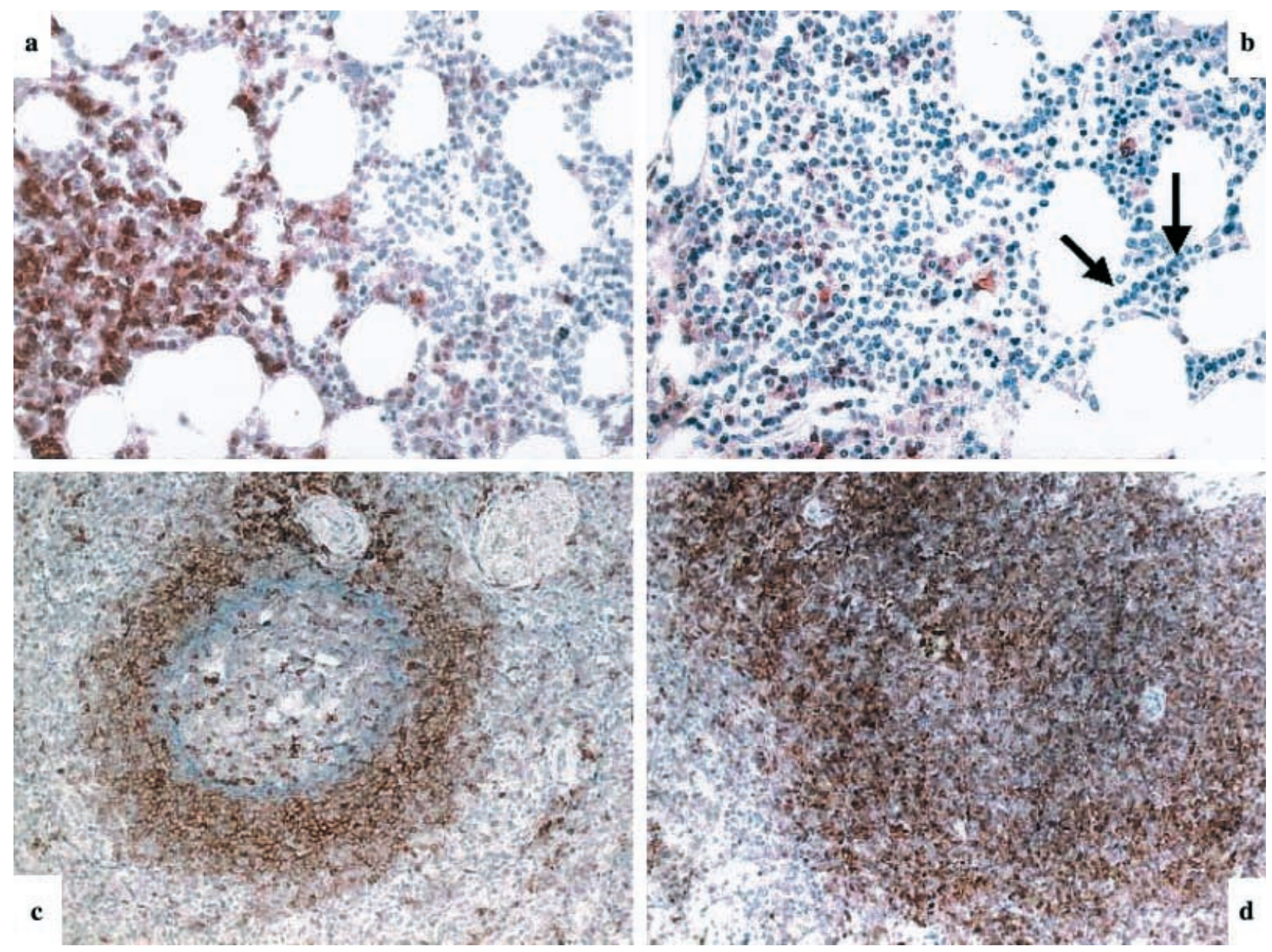

Figure 1. a, CD27 expression in nodular infiltration of a bone marrow biopsy specimen in a case of splenic marginal zone lymphoma (SMZL). b, Intrasinusoidal infiltration of bone marrow (arrows) shows CD27 negativity. c, Marginal zone of traumatic spleen is demarcated by CD27+ cells. d, Neoplastic CD27+ nodule in spleen with SMZL (ABC method).

marker of memory B cells. ${ }^{8}$ Molecular analysis for mutated Ig gene rearrangements have confirmed that CD27 expression distinguishes naive and memory B cells. ${ }^{21}$ Within the $\mathrm{CD} 27+$ B-cell pool, further heterogeneity of subsets has been described, based on the expression of immunoglobulin surface markers. ${ }^{22}$ Patients with primary immunodeficiency disorders, in whom a primary defect interferes with germinal centre reaction and generation of memory $B$ cells, show a predominance of $\mathrm{CD} 27+\mathrm{B}$ cells, perhaps reflecting a compensatory process with respect to B-cell differentiation or function. ${ }^{23}$ Expansion of mutated $\mathrm{CD} 27+$ $\mathrm{B}$ cells originating from the marginal zone compartment has been reported in persistent polyclonal B lymphocytosis. ${ }^{24,25}$ Naive B-cell expansion in the peripheral blood is seen in one-third of hepatitis $\mathrm{C}$ virus-positive patients and is not associated with Ag-mediated activation and differentiation. ${ }^{26}$
Mature lymphoid neoplasia in bone marrow encompasses several distinct clinicopathological entities. Although they are currently classified according to their presumed normal counterpart, their origin in relation to lymphocyte ontogeny is largely unknown.

Chronic lymphocytic leukaemia (CLL), which is the most prevalent adult leukaemia in Western countries, has been widely investigated in order to understand its histogenesis and provides a model for comparison with other chronic B-cell leukaemia/lymphomas. Previously considered to have a low propensity to undergo $\operatorname{IgV}(\mathrm{D}) \mathrm{J}$ gene hypermutation, ${ }^{27-31}$ CLL is now known to show an $\operatorname{IgV}_{\mathrm{H}}$ gene somatic point-mutation in more than half of the cases. ${ }^{32-37}$ Approximately $90 \%$ of cases express $\mathrm{CD} 27$, implying that virtually all B-CLL cases derive from antigen-experienced and memory B lymphocytes. ${ }^{38}$ However, the latter study 
was performed on peripheral blood cells. It is not known if marrow lymphocytes in B-CLL express CD27 as well.

SMZL is a relatively rare type of low-grade non Hodgkin's B-cell lymphoma with morphological and immunophenotypic features resembling splenic marginal zone cells. ${ }^{39}$ Splenic marginal zone cells have been considered to serve as antigen-binding and transporting cells and are capable of transforming into plasma cells. ${ }^{40}$ Activation, proliferation and the immunoglobulin secretory response of splenic marginal zone B cells are distinctive. They are the first line in the immune reaction against blood-borne antigens, ${ }^{41}$ such as bacterial capsular polysaccharide typical of a thymus independent type 2 response. In patients with WiskottAldrich syndrome or during infancy, TI-2 responses are impaired and marginal zone cells are in fact reduced. ${ }^{42,43}$ In a small percentage of cases, SMZL is characterized by the presence in the peripheral blood of lymphocytes with villous projections, which has been termed splenic lymphoma with villous lymphocytes. ${ }^{44}$ Although this name implies a precise origin from the splenic marginal zone, its histogenesis is a matter of debate, since there is no specific marker for splenic marginal zone cells. ${ }^{45}$ An origin from memory B cells was initially supposed. ${ }^{46}$ The constant involvement of bone marrow either intrasinusoidally or as a mixed intrasinusoidal/nodular form is universally acknowledged, ${ }^{4-51}$ and this fact could raise questions about its splenic origin. In the present study, constant CD27 negativity has been observed in the neoplastic cells of the bone marrow intrasinusoidal infiltration. Conversely, when neoplastic cells are in a nodular bone marrow infiltration or in the splenic marginal zone, they express CD27. Previous studies indicate that a nodular pattern of bone marrow infiltration follows the intrasinusoidal one. ${ }^{52}$ It is therefore conceivable that neoplastic B cells in the nodules could have experienced antigen while the intrasinusoidal ones have not.

Clonal heterogeneity affecting residues in the hypervariable region within a tumour is taken to imply continuing antigenic drive during the process of transformation.

In SMZL, evidence of ongoing mutation of $\operatorname{IgV}_{\mathrm{H}}$ gene was originally observed by Dunn-Walters et al. ${ }^{53}$ Diversity in mutational status and initiation of somatic mutation have been demonstrated in vivo by Zhu et al. in a limited number of patients. ${ }^{54}$ Recently, in a series of six cases randomly selected from 23 cases of SMZL, Tierens et al. confirmed that ongoing somatic hypermutation is a prominent feature of SMZLL. ${ }^{55}$ In the same study they found no statistically significant correlation between immunoglobulin mutation status and clinical, immunophenotypic, or genetic characteristics. Human bone marrow is an important destination in the route of recirculating memory cells. ${ }^{56}$ It is not known whether this can happen without involvement of germinal centres. In mice, Körner et al. demonstrated that recirculating and marginal zone B-cell populations can be generated and maintained independently of follicles. ${ }^{57}$

According to the results of the present study, one can hypothesize that in SMZL a naive B-cell population in the bone marrow proliferates and after antigenic stimulation accumulates in the splenic marginal zone, in the bone marrow and other sites. It is clear that further studies are needed to verify this hypothesis.

\section{Acknowledgements}

Supported by a grant of MIUR, Rome (Italy). The authors thank Dr Sabrina Ingrao and Rossana Porcasi for immunohistochemical staining.

\section{References}

1. Tangye SG, Liu YJ, Aversa G, Phillips JH, de Vries J. Identification of functional human splenic memory B cells by expression of CD148 and CD27. J. Exp. Med. 1998; 188; 1691-1703.

2. Tesselaar K, Xiao Y, Arens R et al. Expression of the murine CD27 ligand CD70 in vitro and in vivo. J. Immunol. 2003; 170; $33-40$.

3. Agematsu K, Hokibara S, Nagumo H, Komiyama A. CD27: a memory B-cell marker. Immunol. Today 2000; 21; 204-206.

4. Agematsu K. Memory B cells and CD27. Histol. Histopathol. 2000; 15; 573-576.

5. Klein U, Rajewsky K, Kuppers R. Human immunoglobulin (Ig)M+IgD+ peripheral blood B cells expressing the CD27 cell surface antigen carry somatically mutated variable region genes: $\mathrm{CD} 27$ as a general marker for somatically mutated (memory) B cells. J. Exp. Med. 1998; 188; 1679-1689.

6. Morse HC 3rd, Kearney JF, Isaacson PG, Carroll M, Fredrickson TN, Jaffe ES. Cells of the marginal zone-origins, function and neoplasia. Leuk. Res. 2001; 25; 169-178.

7. Dammers PM, Visser A, Popa ER, Nieuwenhuis P, Kroese FG. Most marginal zone $\mathrm{B}$ cells in rat express germline encoded Ig VH genes and are ligand selected. J. Immunol. 2000; 165; 6156-6169.

8. Zandvoort A, Lodewijk ME, de Boer NK, Dammers PM, Kroese FG, Timens W. CD27 expression in the human splenic marginal zone: the infant marginal zone is populated by naïve B cells. Tissue Antigens 2001; 58; 234-242.

9. Miranda RN, Cousar JB, Hammer RD, Collins RD, Vnencak-Jones CL. Somatic mutation analysis of IgH variable regions reveals that tumor cells of most parafollicular (monocytoid) B-cell lymphoma, splenic marginal zone B-cell lymphoma, and some hairy cell leukemia are composed of memory B lymphocytes. Hum. Pathol. 1999; 30; 306-312.

10. Algara P, Mateo MS, Sanchez-Beato M et al. Analysis of the $\operatorname{IgV}(\mathrm{H})$ somatic mutations in splenic marginal zone lymphoma defines a group of unmutated cases with frequent $7 \mathrm{q}$ deletion and adverse clinical course. Blood 2002; 99; 1299-1304. 
11. Bahler DW, Pindzola JA, Swerdlow SH. Splenic marginal zone lymphomas appear to originate from different B cell types. Am. J. Pathol. 2002; 161; 81-88.

12. Sekikawa T, Takahara S, Kawano et al. No $\mathrm{V}(\mathrm{H})$ somatic hypermutation was detected in B-cells of a patient with macroglobulinemia due to splenic marginal zone lymphoma. Int. J. Hematol. 2002; 76; 453-459.

13. Cariappa A, Pillai S. Antigen-dependent B-cell development. Curr. Opin. Immunol. 2002; 14; 241-249.

14. Allman DM, Ferguson SE, Lentz VM, Cancro MP. Peripheral B cell maturation II. Heat stable antigen ${ }^{\text {hi }}$ splenic B cells are an immature developmental intermediate in the production of long lived marrow derived B cells. J. Immunol. 1993; 151; 4431-4444.

15. Tonegawa S. Somatic generation of antibody diversity. Nature 1983; 302; 575-581.

16. Griffiths GM, Berek C, Kaartinen M, Milstein C. Somatic mutation and the maturation of immune response to 2-phenyl oxazolone. Nature 1984; 312; 271-275.

17. Yancopoulos GD, Alt FW. Regulation of the assembly and expression of variable-region genes. Аnпu. Rev. Immunol. 1986; 4; 339-368.

18. Stephenson FK, Spellerberg MB, Treasure J et al. Differential usage of an Ig heavy-chain variable region gene by human B-cell tumors. Blood 1993; 82; 224-230.

19. Zhu D, Hawkins RE, Hamblin TJ, Stevenson FK. Clonal history of a human follicular lymphoma as revealed in the immunoglobulin variable region genes. Br. J. Hematol. 1994; 86; 505-512.

20. Cebra JJ, Komisar JL, Schweitzer PA. CH isotype 'switching' during normal B-lymphocyte development. Annu. Rev. Immunol. 1984; 2; 493-548.

21. Hansen A, Odendahl M, Reiter K et al. Diminished peripheral blood memory B cells and accumulation of memory B cells in the salivary glands of patients with Sjögren's syndrome. Arthritis Rheum. 2002; 46; 2160-2171.

22. Martens UM, Brass V, Sedlacek L et al. Telomere maintenance in human B lymphocytes. Br. J. Haematol. 2002; 119; 810-818.

23. Jacquot S, Macon-Lemaitre L, Paris E et al. B cell co-receptors regulating $\mathrm{T}$ cell-dependent antibody production in common variable immunodeficiency: CD27 pathway defects identify subsets of severely immuno-compromised patients. Int. Immunol. 2001; 13; 871-876.

24. Loembe MM, Neron S, Delage R, Darveau A. Analysis of expressed $\mathrm{V}(\mathrm{H})$ genes in persistent polyclonal B cell lymphocytosis reveals absence of selection in $\mathrm{CD} 27+\operatorname{IgM}+\operatorname{IgD}+$ memory B cells. Eur. J. Immunol. 2002; 32; 3678-3688.

25. Salcedo I, Campos-Caro A, Sampalo A, Reales E, Brieva JA. Persistent polyclonal B lymphocytosis: an expansion of cells showing $\mathrm{IgVH}$ gene mutations and phenotypic features of normal lymphocytes from the $\mathrm{CD} 27+$ marginal zone B-cell compartment. Br. J. Haematol. 2002; 116; 662-666.

26. Ni J, Hembrador E, Di Bisceglie AM et al. Accumulation of B lymphocytes with a naive, resting phenotype in a subset of hepatitis C patients. J. Immunol. 2003; 170; 3429-3439.

27. Meeker TC, Grimaldi JC, O'Rourke R, Loeb J, Juliusson G, Einhorn $\mathrm{S}$. Lack of detectable somatic hypermutation in the $\mathrm{V}$ region of the Ig $\mathrm{H}$ chain gene of a human chronic B lymphocytic leukemia. J. Immunol. 1988; 141; 3994-3998.

28. Pratt LF, Rassenti L, Larrick J, Robbins B, Banks PM, Kipps TJ. Ig V region gene expression in small lymphocytic lymphoma with little or no somatic hypermutation. J. Immunol. 1989; 143; 699-705.

29. Kuppers R, Gause A, Rajewsky K. B cells of chronic lymphatic leukemia express V genes in unmutated form. Leuk. Res. 1991; 15; 487-496.
30. Friedman DF, Moore JS, Erikson J et al. Variable region gene analysis of an isotype-switched (IgA) variant of chronic lymphocytic leukemia. Blood 1992; 80; 2287-2297.

31. Rassenti LZ, Kipps TJ. Lack of extensive mutations in the VH5 genes used in common B cell chronic lymphocytic leukemia. J. Exp. Med. 1993; 177; 1039-1046.

32. Cai J, Humphries C, Richardson A, Tucker PW. Extensive and selective mutation of a rearranged VH5 gene in human B cell chronic lymphocytic leukemia. J. Exp. Med. 1992; 176; 10731081.

33. Hashimoto S, Wakai M, Silver J, Chiorazzi N. Biased usage of variable and constant-region Ig genes by $\operatorname{IgG}+, \mathrm{CD} 5+$ human leukemic B cells. Ann. NY Acad. Sci. 1992; 651; 477-479.

34. Schroeder HW Jr, Dighiero G. The pathogenesis of chronic lymphocytic leukemia: analysis of the antibody repertoire. Immunol. Today 1994; 15; 288-294.

35. Hashimoto S, Dono M, Wakai M et al. Somatic diversification and selection of immunoglobulin heavy and light chain variable region genes in $\mathrm{IgG}+\mathrm{CD} 5+$ chronic lymphocytic leukemia B cells. J. Exp. Med. 1995; 181; 1507-1517.

36. Oscier DG, Thompsett A, Zhu D, Stevenson FK. Differential rates of somatic hypermutation in $\mathrm{V}(\mathrm{H})$ genes among subsets of chronic lymphocytic leukemia defined by chromosomal abnormalities. Blood 1997; 89; 4153-4160.

37. Fais F, Ghiotto F, Hashimoto $\mathrm{S}$ et al. Chronic lymphocytic leukemia B cells express restricted sets of mutated and unmutated antigen receptors. J. Clin. Invest. 1998; 102; 1515-1525.

38. Damle RN, Ghiotto F, Valetto A et al. B-cell chronic lymphocytic leukemia cells express a surface membrane phenotype of activated, antigen-experienced B lymphocytes. Blood 2002; 99; 4087-4093.

39. Isaacson PG, Piris MA, Catovski D et al. Splenic marginal zone lymphoma. In Jaffe ES, Harris NL, Stein H, Vardiman JW eds. Tumors of haematopoietic and lymphoid tissues. WHO Classification of Tumors. Lyon: IARC Press, 2001; 135-137.

40. Martin F, Kearney JF. Marginal-zone B cells. Rev. Immunol. 2002; 2; 323-335.

41. Oliver AM, Martin F, Gartland GL, Carter RH, Kearney JF. Marginal zone B cells exhibit unique activation, proliferative and immunoglobulin secretory response. Eur. J. Immunol. 1997; 27; 2366-2374.

42. Timens W, Boes A, Rozeboom Uiterwijk T, Poppema S. Immaturity of the human splenic marginal zone in infancy. Possible contribution to the deficient infant immune response. J. Immunol. 1989; 143; 3200-3206.

43. Vermi W, Blanzuoli L, Kraus MD et al. The spleen in the WiskottAldrich syndrome: histopathologic abnormalities of the white pulp correlate with the clinical phenotype of the disease. Am. J. Surg. Pathol. 1999; 23; 182-191.

44. Franco V, Florena AM, Iannitto E. Splenic marginal zone lymphoma. Blood 2003; 101; 2464-2472.

45. Arcaini L, Paulli M, Boveri E, Magrini U, Lazzarino M. Marginal zone-related neoplasms of splenic and nodal origin. Haematologica 2003; 88; 80-93.

46. Katayama Y, Kojima K, Yoshino T et al. Memory B cell in spleen is the origin of splenic lymphoma with villous lymphocytes. Blood 1996; 88 (Part 1, Suppl. 1): 945 (Abstract).

47. Franco V, Florena AM, Campesi G. Intrasinusoidal bone marrow infiltration: a possible hallmark of splenic lymphoma. Histopathology 1996; 29; 571-575.

48. Labouyrie E, Marit G, Vial JP et al. Intrasinusoidal bone marrow involvement by splenic lymphoma with villous lymphocytes: a helpful immunohistologic feature. Mod. Pathol. 1997; 10; 1015-1020. 
49. Kent SA, Variakoijs D, Peterson LC. Comparative study of marginal zone lymphoma involving bone marrow. Am. J. Clin. Pathol. 2002; 117; 698-708.

50. Costes V, Duchayne E, Taib J et al. Intrasinusoidal bone marrow infiltration: a common growth pattern for different lymphoma subtypes. Br. J. Haematol. 2002; 119; 916-922.

51. Audouin J, Le Tourneau A, Molina T et al. Patterns of bone marrow involvement in 58 patients presenting primary splenic marginal zone lymphoma with or without circulating villous lymphocytes. Br. J. Haematol. 2003; 122; 404-412.

52. Franco V, Florena AM, Stella M et al. Splenectomy influences bone marrow infiltration in patients with splenic marginal zone cell lymphoma with or without villous lymphocytes. Cancer 2001; 91; 294-301.

53. Dunn-Walters DK, Boursier L, Spencer J, Isaacson PG. Analysis of immunoglobulin genes in splenic marginal zone lymphoma suggests ongoing mutation. Hum. Pathol. 1998; 29; 585-593.

54. Zhu D, Orchard J, Oscier DG, Wright DH, Stevenson FK. V(H) gene analysis of splenic marginal zone lymphomas reveals diversity in mutational status and initiation of somatic mutation in vivo. Blood 2002; 100; 2659-2661.

55. Tierens A, Delabie J, Malecka A et al. Splenic marginal zone lymphoma with villous lymphocytes shows on-going immunoglobulin gene mutations. Am. J. Pathol. 2003; 162; 681-689.

56. Paramithiotis E, Cooper MD. Memory B lymphocytes migrate to bone marrow in humans. Proc. Natl Acad. Sci. USA 1997; 94; $208-212$.

57. Körner H, Winkler TH, Sedgwick JD, Rollinghoff M, Basten A, Cook MC. Recirculating and marginal zone B cell populations can be established and maintained independently of primary and secondary follicles. Immunol. Cell Biol. 2001; 79; 54-61. 